\title{
IFNAR1 wt Allele
}

National Cancer Institute

\section{Source}

National Cancer Institute. IFNAR1 wt Allele. NCI Thesaurus. Code C51352.

Human IFNAR1 wild-type allele is located in the vicinity of 21q22.11 and is approximately $35 \mathrm{~kb}$ in length. This allele, which encodes interferon alpha/beta receptor 1 protein, is involved in tyrosine-kinase signal transduction and receptor mediation to regulate innate immune responses to viral infection. 